\title{
A History of Arab-Islamic Geography (9th-16th Century AD)
}

\author{
By Sayyid Maqbool Ahmad. Amman: Al Ahl-Bayt University, 1995, 454 \\ pp. with maps, index, and bibliography.
}

"Everything you ever wanted to know about the Arab-Islamic contribution to geography (but have had no time to learn up to now)," aptly describes Sayyid Maqbool Ahmad's A History of Arab-Islamic Geography, which is a description of the Arab-Islamic contribution to geography between the sixth and nineth centuries. To the uninitiated reader, the book may seem like a spider's web; there is a guiding thread to follow, but that thread is hard to find and easy to lose. Barring language difficulty and the insipid organization of the text, the book is monumental. It clarifies a number of misconceptions and provides authentic details about Arab-Islamic geography.

The book is based on over 50 years of painstaking research of Arabic palimpsests and chronicles and their translations into English and other European languages. It was the late Professor Hamilton Gibb of St. Johns College (Oxford University), a shining light among Western Orientalists, who asked Ahmad in 1945 for research on the subject. Following his mentor, Ahmad has done a remarkable job of distilling much of the chaotic and contentious matters relating to Arab-Islamic geography. Never before has anyone attempted to provide detailed "basic data" on Arab-Islamic geography. Contrary to what many Western Orientalists believe, the Arabs - in addition to being inheritors and preservers of Greek, Indian, and Persian knowledge-made significant contributions to geography. It was partly the contribution of Nasir al-Din Tusi (astronomy), al-Battani (astronomy), Mohammed Musa al-Khwarizmi (mathematics), Ibn al-Haytham (optics), Abul-Rayhan al-Biruni (astronomy, physics), Ibn Sina (medicine), Al-Jazari (mechanics), Al-Sharif al-Idrisi (geography), AlMasudi (geography), Ibn al-Nafis (blood circulation), Ibn Majid (magnetic compass), and others to science and technology that motivated the Industrial Revolution of Europe.

The book is organized into two parts and twenty-two chapters to present the vast literature by subject and chronological order. Part I of the book has three sections and nine chapters, which discuss the origins of scientific geography, astronomical and philosophical literature, reports of the explorers and Arab embassies, and regional discussions. These chapters are conclusive that ArabIslamic scientific geography began with $\mathrm{Al}-\mathrm{Ma}$ 'mun (813-833 $\mathrm{AD}$ ), who established the first academy, known as Bayt al-Hikma (the House of Wisdom). As a result, in Baghdad after the middle of the ninth century, general and descriptive geographical works began appearing. Included in this section are also chapters on the Iraqi and Balkhi school of geography. Chapters 10 through 15 discuss the important regional, philosophical, and astronomical geography works which appeared in Baghdad. Ibn Khurdadbih was the first writer on the subject and hence can be called the father of Arab-Islamic geography. His Kitab al-Masalik wa al-Mamalik (Book of Roads and Kingdoms) is a classic.

Two appendices, one concerning the Waqwaq Islands and the other concerning Modification of Ptolemy's Geography by Al-Idrisi, are the most revealing parts of the book because the location of the Waqwaq Islands and Al-Idrisi's modification of Ptolemy's map have long baffled Orientalists. Waqwaq Islands (al-Juzur al-Waqwaq) were first mentioned in Ibn Khurdashbih's Kitab alMasalik wa al-Mamalik. Appendix 2, Al-Idris's modification of Ptolemy's map, 
is interesting in the sense that it corrects a number of Ptolemy's statements and gives details of the Mediterranean, Caspian, and Black Seas, in addition to the Indian Ocean and the mountains and rivers of Europe and of other continents.

Barring some spelling mistakes in printing, the book is a monumental work on Arab-Islamic geography. Professor Ahmad deserves all our praise for undertaking such research. We should also be grateful to His Majesty Hussein Ibn Talal, King of Jordan, to whom the book has been dedicated. Unlike other monarchs, King Hussein identifies himself more with academia and runs Ahl al-Bayt University from his personal funds.

Mushtaqur Rahman Geography Department Iowa State University Ames, lowa 